Case Study

\title{
Planning Process for Drinking Water Protection: Case Study of Kartalkaya Dam Basin
}

\section{İçme Suyu Kaynaklarının Korunmasına Yönelik Planlama Süreci: Kartalkaya Baraj Havzası Örneği}

\author{
Çiğdem ÖZONAT \\ Ministry of Forestry and Water Affairs, Directorate General for Water Management \\ Yenimahalle-Ankara-Turkey \\ cozonat@ormansu.gov.tr
} Received Date: 13.12.2017, Accepted Date: 28.12.2017

\begin{abstract}
Access to safe drinking water is vital for public health. Therefore, protection of these water resources is among major responsibilities of governments in order to ensure continuous supply of safe drinking water to citizens. On the other hand, drinking water resources are under severe risks throughout the world due to pollution, unsustainable use, climate change and many other effects. In order to minimize these risks, source water protection is accepted as most effective planning approach. In this study, Kartalkaya Dam was selected as a case study to discuss the theoretical framework of source water protection planning. Kartalkaya Dam is the only surface drinking water resource for Gaziantep Province. However, its water quality is at risk of deteriorating due to pollutant activities in the basin. This situation has created a need to execute a source water protection study in the Kartalkaya Dam Basin on the purpose of identifying and prioritizing management actions to bring water contamination risks to an acceptable level. Within this study, it was started with basin characterization and water quality assessment. A coupled model was developed to simulate quality for alternative future scenarios. Simulated results showed that Kartalkaya dam will be mesotrophic in case of providing $50 \%$ reduction in TN and 25\% reduction in TP. Based on specified rates, pollution reduction measures were suggested. As a result of cost-benefit analysis, it is concluded that recommended measures are feasible.
\end{abstract}

Keywords: drinking water, source water protection, pollution reduction, modelling, costbenefit analysis

\section{$\ddot{O} z$}

Güvenli içme suyuna erişim kamu sağlığı için hayati önem taşımaktadır. Bu nedenle, vatandaşlara güvenli içme suyunu devamlı sağlayabilmek için bahse konu su kaynaklarının korunması devletlerin en önemli görevleri arasında yer almaktadır. Ancak, içme suyu kaynakları kirlilik, aşırı su kullanımı, iklim değişikliği ve benzeri nedenlerle önemli riskler altındadır. Bu risklerin azami düzeye indirilmesi için kaynakta koruma çalışmaları en etkili planlama yaklaşımı olarak kabul edilmektedir. Bu çalışmada, Kartalkaya Barajı su kaynaklarının korunmasına yönelik yapılan planlama çalışmalarının teorik çerçevesini değerlendirmek üzere bir vaka çalışması olarak seçilmiştir. Kartalkaya Barajı, Gaziantep için tek yüzeysel içme suyu kaynağı olmakla birlikte havzadaki kirletici faaliyetler nedeniyle barajdaki 
su kalitesi bozulma riski altındadır. Bu durum, Kartalkaya Baraj Havzasında içme suyu koruma planının yürütülmesi ihtiyacını doğurmuş olup; bahse konu plan ile havzadaki kirletici risklerinin kabul edilebilir seviyelere gelmesini sağlayacak eylemlerin belirlenmesi ve önceliklendirilmesi amaçlanmıştır. Bu çalışma kapsamında, öncelikle havzanın özellikleri ve mevcut su kalitesinin durumu değerlendirilmiştir. Alternatif gelecek senaryoları için su kalitesini öngörmek maksadıyla birleşik su kalite modeli geliştirilmiştir. Model sonuçları, toplam azotun \% 50 toplam fosforun ise $\% 25$ azalması durumunda Kartalkaya Barajı'nın mezotrofik olacağını ortaya koymuştur. Belirlenen oranlara dayanarak kirliliğin azalmasını sağlayacak tedbirler geliştirilmiştir. Fayda-maliyet analizi neticesinde önerilen tedbirlerin uygulanabilir olduğu sonucuna varılmıştır. analizi

Anahtar sözcükler: içme suyu, kaynak koruma, kirliliğin azaltılması, modelleme, fayda-maliyet

\section{Introduction}

Safe drinking water is the primary need of every human being. However, quality of drinking water resources is threatened by a variety of potential point and nonpoint sources of pollution. Therefore, protecting these water resources from contaminants is always among the top priorities of the governments in order to supply safe drinking water to citizens. This is best achieved through implementing an effective source water protection to prevent pollution problems from developing in the first place. Source water protection can be explained as basin-based planning process which aims at protecting a drinking water source through pollution reduction policies and land use management activities (Al Ibrahim and Patrick, 2017). The issue of source water protection has been discussed and promoted by different organizations at the international, national, regional and local levels since the National Source Water Protection Conference held by USEPA in 2003, and it is accepted as the first barrier in the multi-barrier system to minimize the risk of contamination in drinking water sources. Additionally, it is defined as a site-specific process which may require different protection programs due to differing characteristics of the watersheds, land use practices, potential pollution sources, as well as the nature of the stakeholder organizations and their available resources (Sklenar et. al, 2012).

Turkey also expresses a great amount of concern relating to water pollution. In order to prevent water pollution, many of laws and regulations specific to drinking water resources and basins have been adopted in last 10 years. Besides taking legal measures, many basin-based drinking water protection studies have been conducted. One of these studies has been executed in Kartalkaya Dam Basin with the aim of identification and prioritization of management actions to mitigate water contamination risks to an acceptable level. Since Kartalkaya Dam is the only surface drinking water resource for Gaziantep Province, it is crucial to take mitigation measures for the protecting the source against water contamination risks. Additionally, 
the protection of this source gains more importance considering the fact that the rapidly growing population due to Syrian asylum seekers has increased the Gaziantep's demand for drinking water. On the other hand, water pollution threatens the sustainability of Kartalkaya Dam. The primary water quality problems include high nutrient concentrations and bacterial contamination. Due to high nitrogen and phosphorus concentrations, Kartalkaya Dam is at risk of eutrophication. The unconscious use of fertilizers and pesticides, inadequate wastewater treatment facilities, improper disposal of waste and animal manure are considered to be the main reasons for pollution in Kartalkaya Dam. In order to minimize these contaminants, the source water protection plan for the Kartalkaya Dam Basin was developed in 2017 by Ministry of Forestry and Water Affairs. Within planning process, many interdisciplinary analyses were conducted to formulate the optimum management strategies. These analyses involve the assessment of the basin characteristics, potential causes of water quality degradation, current and future water quality. In order to simulate future quality, a coupled model was operated for four alternative scenarios. Based on the model results, pollution reduction measures were recommended. Additionally, a preliminary economic analysis was conducted in order to assess whether proposed measures are achievable and realistic. Thusly, all essential tools of source water protection was integrated into management planning process.

The purpose of this paper is to present not only the results of Kartalkaya Dam Basin Protection Planning but also a roadmap toward establishing a comprehensive source water protection plan.

\section{Method}

This paper undertakes a case study approach into drinking water protection planning in Kartalkaya Dam Basin. It was chosen as a case study because the study conducted in the basin can be shown as a good example for integration of all essential tools of source water protection to planning process.

In the scope of study, firstly, demographic, socio-economic, physical structures, and existing land use were determined in order to present the current situation of basin. As a second step, point and diffuse pollution sources were evaluated, and monitoring studies were conducted to identify current water quality. Thirdly, a coupled water quality model for the Kartalkaya Dam Basin was developed to support the scenario analysis. Based on the model results, a basin protection plan was recommended. Finally, a preliminary economic assessment was conducted for the measures proposed in the protection plan. The technical approach of the study is illustrated in Figure 1. 


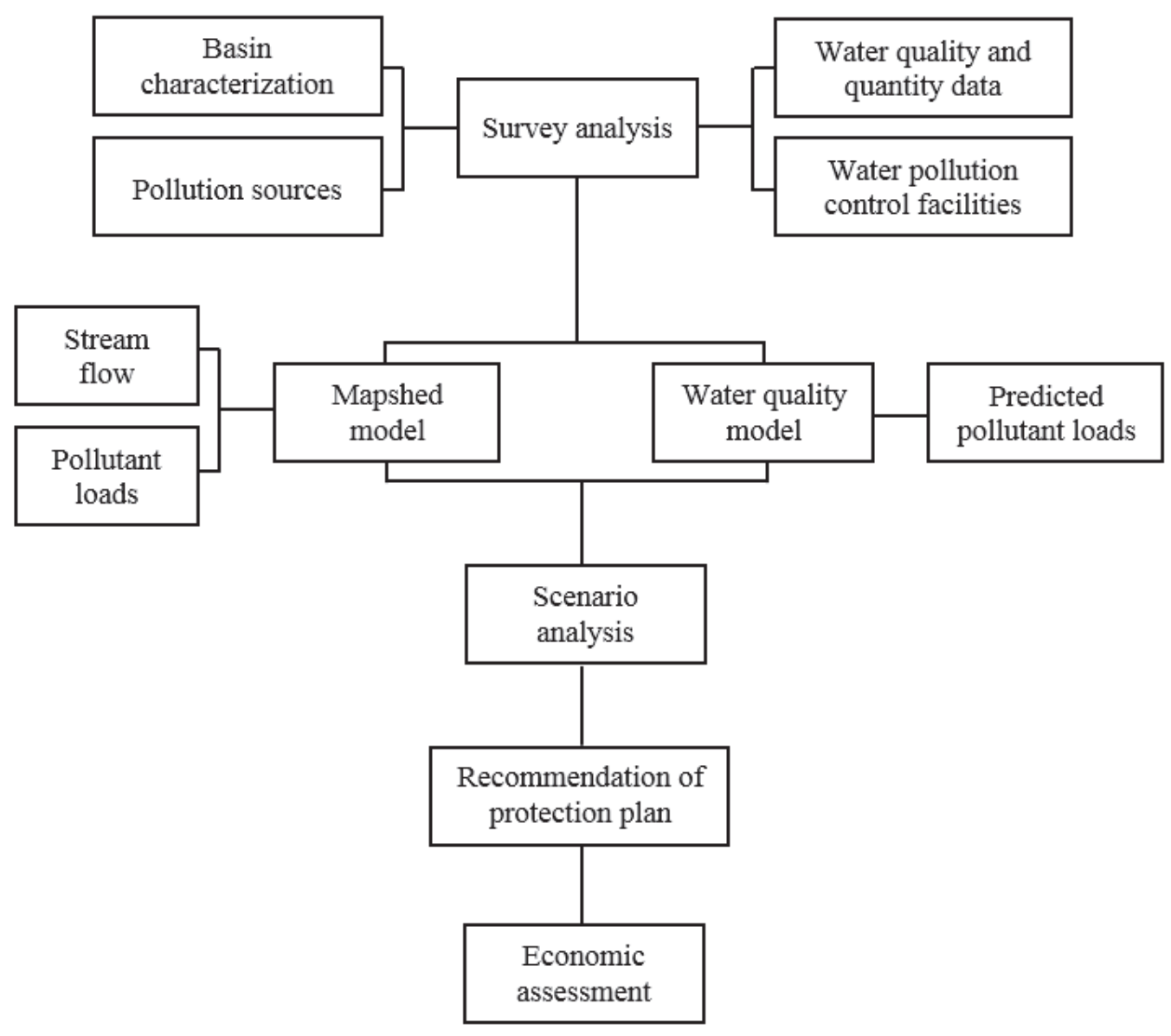

Figure 1. Technical approach of the study.

\section{Study Area}

The Kartalkaya Dam was built on the Aksu River between 1965 and 1970 in order to supply water for irrigation. Since 1986, the dam has started to be used both for irrigation and drinking water purposes. In current situation, annually $94.6 \mathrm{hm}^{3}$ of drinking water is supplied from Kartalkaya Dam to Gaziantep Province and it is the only surface drinking water resource for the city. 


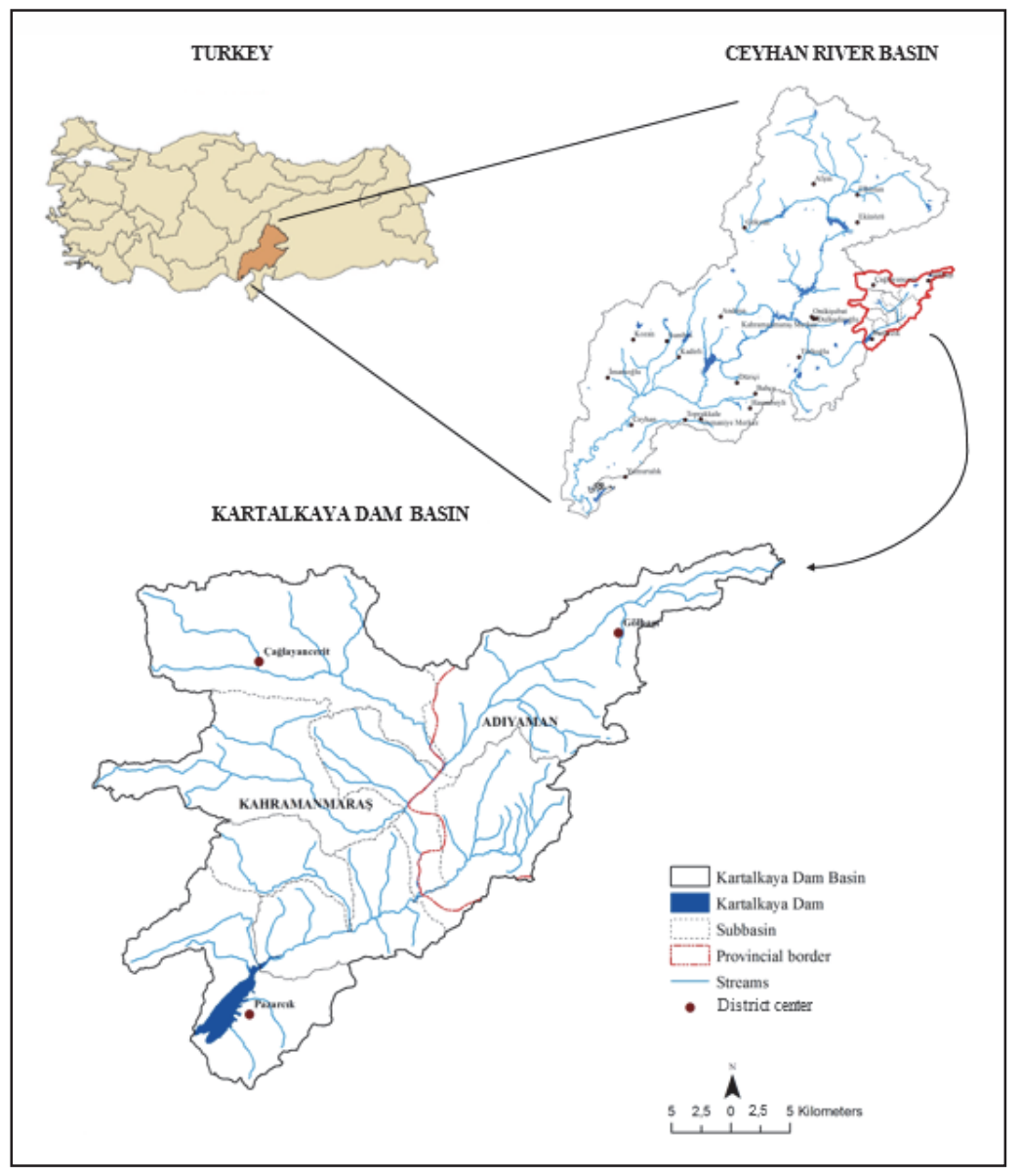

Figure 2. The location of Kartalkaya Dam Basin.

The Kartalkaya Dam has a reservoir area of $11 \mathrm{~km}^{2}$ and a drainage area of 1088 $\mathrm{km}^{2}$. The drainage area of Kartalkaya Dam covers 3 districts (Pazarcık, Çağlayancerit and Gölbaş1) and 54 villages. According to the 2016 census of Turkey, approximately 100.000 people live within the basin. The land use pattern in the Kartalkaya Dam Basin displays a typical rural region characteristic. The agricultural areas represent $59 \%$ of basin area, while pasture lands and forested areas account for 24\% and 16\% respectively. On the other hand, artificial areas (e.g. settlements, industrial plants) occupy a remarkably low ratio.

Since more than the half of basin area is used as cropland, agricultural runoff is the primary contaminant that currently threatens the water quality of Kartalkaya Dam. 
Animal manure is an important secondary pollution source as a result of intensive livestock production. Disposal of untreated or inadequately treated domestic and industrial wastewater, and dump sites can be counted as other pollution sources that cause degradation in water quality of the dam.

\section{Field Survey}

Monitoring studies were conducted between April to December 2016, and measurements were performed at four distinct times in each seasons. The water samples were taken from 10 sites along the influent streams and 8 sites in the reservoir (see Figure 3). These sites were chosen based on location of pollution sources.

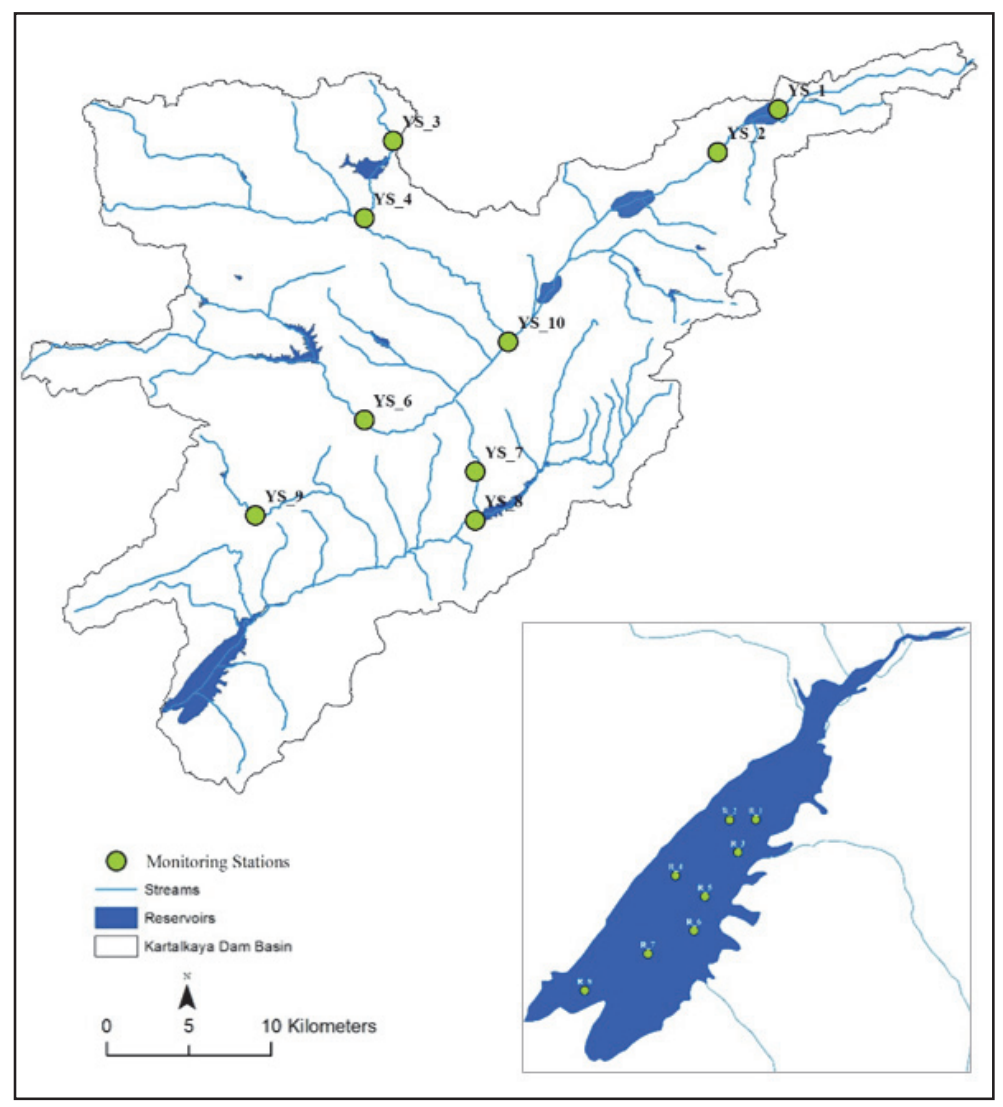

Figure 3. Location of sampling sites.

The water samples collected from streams were analyzed for 36 parameters listed in "By-Law on Surface Water Quality" and analysis results were evaluated according 
to the quality categories (Class I, Class II, Class III, Class IV) specified in the same regulation. On the other hand, the samples taken from reservoir were analyzed for 41 parameters listed in "By-Law on Quality of Surface Waters Used or Planned to Use for Drinking Water Supply" and analysis results were evaluated with accordance to the quality categories (A1, A2, A3) specified in this regulation.

Besides on-site monitoring and analysis studies, some existing hydro-chemical, hydraulic and climate datasets were collected from different public institutions. These datasets were used not only to assess status of water quality and quantity but also to calibrate the model.

\section{Water Quality Modelling}

Mathematical models are used as effective tools to forecast the temporal and spatial changes in the quality and quantity of water, to predict the impacts of proposed policies or practices and to select an optimal strategy for sustainable water management (Ziemińska-Stolarska and Skrzypski, 2012; Loucks and van Beek, 2017).

In this study, two different mathematical models were used to evaluate the impact of land use practices on water quality and quantity in Kartalkaya Dam Basin between the years 2017 and 2040. MapShed model, a GIS based watershed modelling tool, was applied in order to determine the stream flows in the basin and the transported pollutant loads into the reservoir. On the other hand, STELLA software, a visual programming language, was used to estimate the effects of the pollutants on the water quality of the reservoir and to stimulate how the water quality has changed through different pollution control strategies.

Mapshed model was based on different sets of data supplied from various providers. Most of the input parameters were obtained from the measured data; on the other hand, the parameters were estimated based on the literature if the data were not available. Table 1 presents all GIS level inputs and their sources.

Mapshed model was run on a daily basis between 2000 and 2012 in order to calculate the flow rate in the basin. The calibration of the model was done using data sets recorded by DSI from 12020002 numbered gauging station on Aksu River. For assessing the goodness of fit of the model, Nash-Sutcliffe Efficiency $\left(\mathrm{N}_{\mathrm{SE}}\right)$ was used. The $\mathrm{N}_{\mathrm{SE}}$ value gives an aggregated measure of predictive power of the model, and values between 0 and 1 indicate that the model is acceptable (Moriasi et al. 2007). Using the calibrated Mapshed model, future stream flow values were estimated with annual periods for the years between 2017 and 2040. Additionally, input was provided 
into the model from the results of the Project on 'The Effects of Climate Change on the Water Resources' (SYGM, 2016). Since MPI-ESM-MR model which is based on RCP4.5 scenario provides the most suitable results for the study area, temperature and precipitation values (2017-2040) from RCP4.5 scenario of MPI-ESM-MR were used in Mapshed model. Thusly, the possible effects of climate change were also taken into account in the future flow rates.

Table 1

Input Parameters for Mapshed Model

\begin{tabular}{|c|c|c|}
\hline Data & Data Format & Data Source \\
\hline $\begin{array}{l}\text { Digital elevation model } \\
\text { (DEM) }\end{array}$ & $\begin{array}{l}\text { Grid (DEM layers with a } \\
\text { scale of } 1 / 25.000 \text { ) }\end{array}$ & $\begin{array}{l}\text { Ministry of Forestry and Water Affairs } \\
\text { - General Directorate of Water } \\
\text { Management }\end{array}$ \\
\hline Soil map & $\begin{array}{l}\text { Polygon (Vector map with a } \\
\text { scale of } 1 / 100.000)\end{array}$ & $\begin{array}{l}\text { Ministry of Food Agriculture and } \\
\text { Livestock - General Directorate of } \\
\text { Agricultural Reform }\end{array}$ \\
\hline $\begin{array}{l}\text { Landuse map } \\
\text { (CORINE data) }\end{array}$ & $\begin{array}{l}\text { Polygon (Vector map with } \\
16 \text { classes) }\end{array}$ & $\begin{array}{l}\text { Ministry of Forestry and Water Affairs } \\
\text { - Department of Information } \\
\text { Technologies }\end{array}$ \\
\hline Basin boundary & Polygon & $\begin{array}{l}\text { Ministry of Forestry and Water Affairs } \\
\text { - General Directorate of Water } \\
\text { Management }\end{array}$ \\
\hline Stream network & Line & $\begin{array}{l}\text { Ministry of Forestry and Water Affairs } \\
\text { - General Directorate of Water } \\
\text { Management }\end{array}$ \\
\hline Weather stations & Point & $\begin{array}{l}\text { Ministry of Forestry and Water Affairs } \\
\text { - General Directorate of Meteorology }\end{array}$ \\
\hline $\begin{array}{l}\text { Weather data (e.g. } \\
\text { daily precipitation, } \\
\text { maximum-minimum } \\
\text { temperature) }\end{array}$ & Table (text file) & $\begin{array}{l}\text { Ministry of Forestry and Water Affairs } \\
\text { - General Directorate of Meteorology }\end{array}$ \\
\hline
\end{tabular}

In addition, MapShed model was operated to estimate concentrations of nutrients (total nitrogen and total phosphorus) in the streams between 2000 and 2012. The results of the water quality monitoring conducted at downstream of Aksu River were used to calibrate the model. Mean absolute error (MAE), root mean square error (RMSE) and relative root mean square error (rRMSE) were employed as model performance coefficients. These indices measure an average magnitude of the errors in a set of predictions. As MAE, RMSE and rRMSE values approach 0, the model results become more acceptable (Moriasi et al. 2007). Using the calibrated Mapshed model, pollutant loads were predicted with annual periods for the years between 2017 and 2040 . 
Additionally, a water quality model was designed on a monthly basis to predict the average water quality in the Kartalkaya Dam. STELLA software program was used to create the model. Eight water quality variables including Dissolved Oxygen, Biochemical Oxygen Demand, Ammonium Nitrogen, Nitrate, Organic Nitrogen, Ortho-Phosphate, Organic Phosphorus and Alg Biomass were employed for the model. The following assumptions were made for the water quality model:

- The model operates monthly.

- The dam consists of two layers, namely epilimnion and hypolimnion layer.

- Water inlet is only from the epilimnion layer and the water outlet is only from the hypolimnion layer.

- Advective movements between layers occur only from the epilimnion layer to the hypolimnion layer.

- Material transport by interdiffusion takes place from more concentrated layers to less concentrated ones

For the calibration of the water quality model, the results of the water quality monitoring conducted in the dam were used. In order to numerically quantify the performance of the model, the coefficient of MAE, RMSE and rRMSE were used. Evaluating the model performance indicators, model parameters were adjusted to minimize the difference between the measured values and the calculated ones.

In the final stage of modelling, four possible future scenarios, which are listed in Table 2, were designed and examined by modelling analyses. Using the calibrated water quality model, the changes occurred at the trophic level of the dam were estimated for alternative future scenarios. In the model, the amount of pollutant loads predicted in MapShed model was used, and the limit values given in the "By-Law on Surface Water Quality" for trophic classification system were taken as basis.

After determining worst-case scenario, the water quality model was run to predict how the water quality will change if the pollution reduction measures are implemented. Based on model results, a pollution reduction scheme was recommended. 
Table 2

Alternative-Future Scenarios for The Kartalkaya Dam Basin

\begin{tabular}{|c|l|l|l|l|l|}
\hline Scenario & $\begin{array}{l}\text { An autonomous } \\
\text { growth of } \\
\text { population and } \\
\text { economy }\end{array}$ & $\begin{array}{l}\text { No } \\
\text { precautions } \\
\text { taken in terms } \\
\text { of pollutant } \\
\text { loads }\end{array}$ & $\begin{array}{l}\text { Continuation } \\
\text { of water } \\
\text { abstraction for } \\
\text { drinking } \\
\text { purpose }\end{array}$ & $\begin{array}{l}\text { No water } \\
\text { abstraction } \\
\text { for drinking } \\
\text { purpose }\end{array}$ & $\begin{array}{l}\text { Changes in } \\
\text { water quality } \\
\text { due to } \\
\text { climate } \\
\text { change }\end{array}$ \\
\hline 1 & $\sqrt{ }$ & $\sqrt{ }$ & $\sqrt{ }$ & \\
\hline 2 & & $\sqrt{ }$ & $\sqrt{ }$ & $\sqrt{ }$ \\
\hline 3 & & & & $\sqrt{ }$ & $\sqrt{ }$ \\
\hline 4 & & & & & \\
\hline
\end{tabular}

\section{Cost and Benefit Analysis}

Evaluating the economic feasibility of proposed measures is critically important to improve the efficiency and effectiveness of pollution reduction schemes. Cost and benefit analysis is a commonly used tool for identifying, valuing and comparing costs and benefits of recommended interventions. The major objective of cost and benefit analysis is to determine whether the benefits of proposed measure outweigh its costs. Thusly, it can be a good indicator to identify whether the proposed measure is a sound investment (Buncle et al., 2013).

In this study, a preliminary economic assessment was conducted for the measures proposed in the Kartalkaya Basin Protection Plan. The objective of this assessment was to calculate monetary values of costs and benefits of proposed measures, and their monetary net effect.

Firstly, a financial and economic assessment was conducted for the cost of measures requiring investment in short-term. Methodology of this assessment comprises the following procedures:

- To identify the type of costs (e.g., fixed costs, variable costs)

- To express the value of costs in monetary values

- To convert the costs realized over time to present day values

- To mapping out the distribution of costs between stakeholders (i.e., water users and inhabitants of the basin)

The second step was to evaluate potential economic benefits generated from water quality improvements. Although the calculation of the monetary value of economic benefits is a complex task, there are some studies to measure the benefits of 
compliance with environmental standards. One of these studies was conducted by ECOTEC (2001) and its results were published in a report including annual benefits of full harmonization with EU environmental standards. Based on the ECOTEC report, the COWI Consultancy has calculated the annual per capita benefit of full compliance with EU environmental standards in Turkey in the context of the "Technical Assistance Project for the Preparation of 15 Wastewater Treatment Plant Projects". According to results of this study, the annual per capita benefit of full compliance with EU environmental standards ranges from $€ 28$ to $€ 68$ (2007 prices). Additionally, in the study, it is indicated that projects investing in only one of the water supply, wastewater collection and wastewater treatment will provide a minimum benefit value of $€ 28$ per person per year while the projects investing in each of these areas will provide a maximum benefit value of $€ 68$ per person per year. These estimated values were taken as basis in order to evaluate the economic benefits of measures proposed in the Kartalkaya Basin Protection Plan.

Finally, the difference between the net present values of total economic benefits and costs was calculated in order to find out whether the measures proposed in the Kartalkaya Basin Protection Plan are sound enough to support their implementation.

\section{Results}

The monitoring results showed that water quality decreased from upstream to downstream. Total kjendhal nitrogen (TKN) concentrations in streams ranged from 0.52 to $10.5 \mathrm{mg} / \mathrm{L}$; and total phosphorus concentrations ranged from 0.01 to $0.99 \mathrm{mg} / \mathrm{L}$. The lowest nutrient concentrations were detected in forest areas while the highest nutrient concentrations occured in agricultural areas and urban areas, particularly near the district of Gölbaş1. Additionally, the results of analysis indicated the bacteriological contamination in all water samples collected from streams, which can be attributed to the discharge of municipal sewage and disposal of animal excreta into the water. Parallel to the analysis results of the stream samples, it was determined that nutrient and bacteriological parameters exceeded acceptable limits in the reservoir. According to these results, current water quality class of the streams ranged from Class II (slightly polluted) to Class IV (heavily polluted); while the quality of the reservoir was classified as A2 (drinkable waters with physical treatment, chemical treatment and disinfection). These analysis results also provided input for the models to perform the calibration.

Using the calibrated models, the impact of land use practices on water quality and quantity of Kartalkaya Dam was evaluated and results were shown as average annual values for the years between 2017 and 2040 . 
The results of MapShed model indicated that total nitrogen (TN) loads will increase from $937.431 \mathrm{~kg} /$ year to $1.069 .621 \mathrm{~kg} /$ year while total phosphorus (TP) loads will increase $27.963 \mathrm{~kg} /$ year to $29.486 \mathrm{~kg} /$ year if no precaution is taken during the projection period of 2017 and 2040. Based on the results, about 10 percent of TN and 60 percent of TP were originated from point sources (see Figure 4). These results showed that both point resources and non-point sources had a role in the nutrient pollution. In other words, the pollutant loads from both point resources and non-point sources should be controlled in order to decrease nutrient concentrations in the basin.
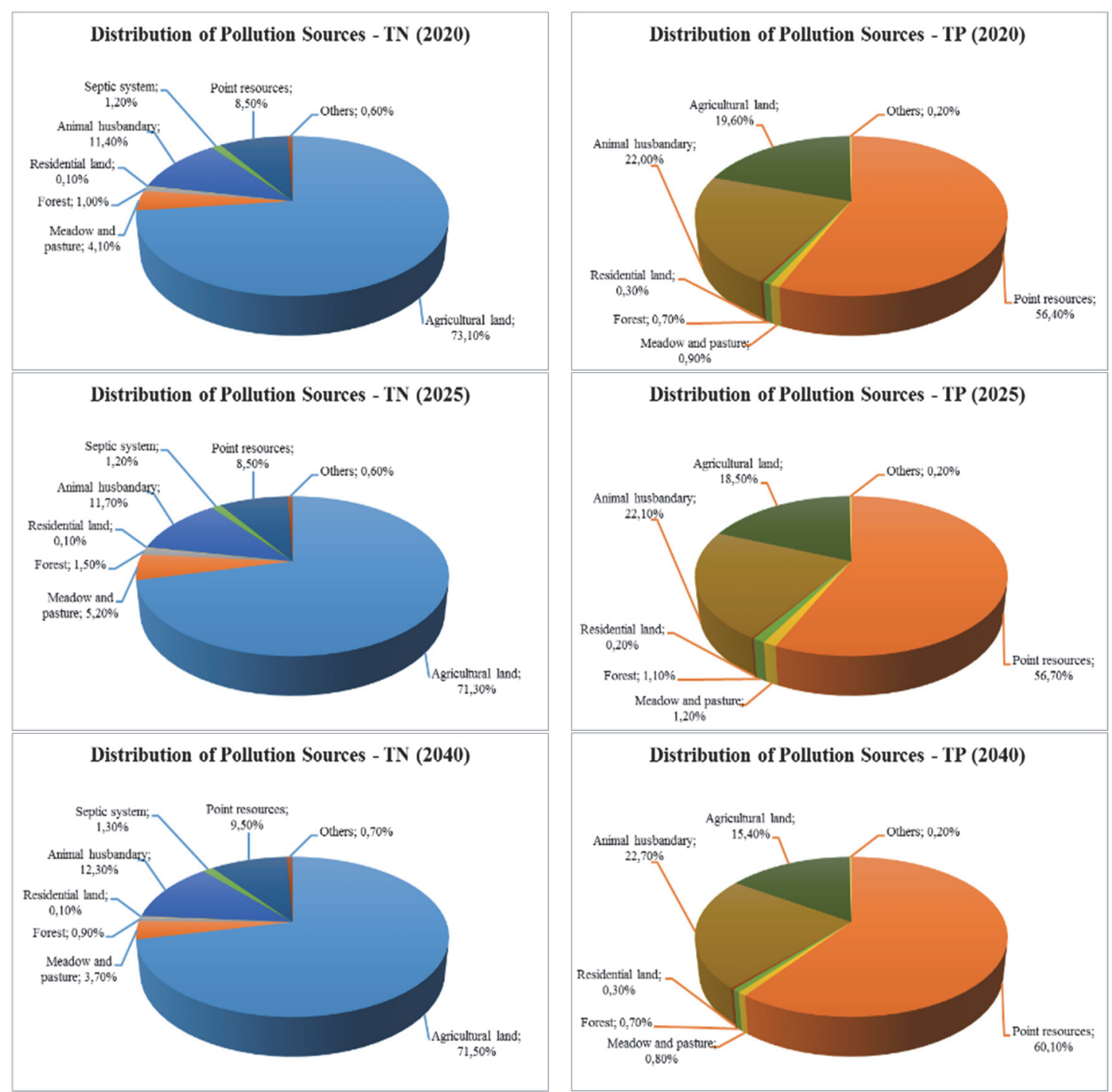

Figure 4. Distribution of pollution sources in the years of 2020, 2025 and 2040. 
Using the predicted nutrient loads, the changes occurred at the trophic level of the dam were estimated for four possible future scenarios. According to the model results, the worst water quality condition for TN and TP was observed respectively in scenario 1 and scenario 4 .

Scenario 1: Assuming an autonomous growth of population and economy with no interventions, it was observed that trophic level of the dam remains hypertrophic in terms of TN until 2040 and it will be mesotrophic in terms of TP after 2020 (see Figure 5).
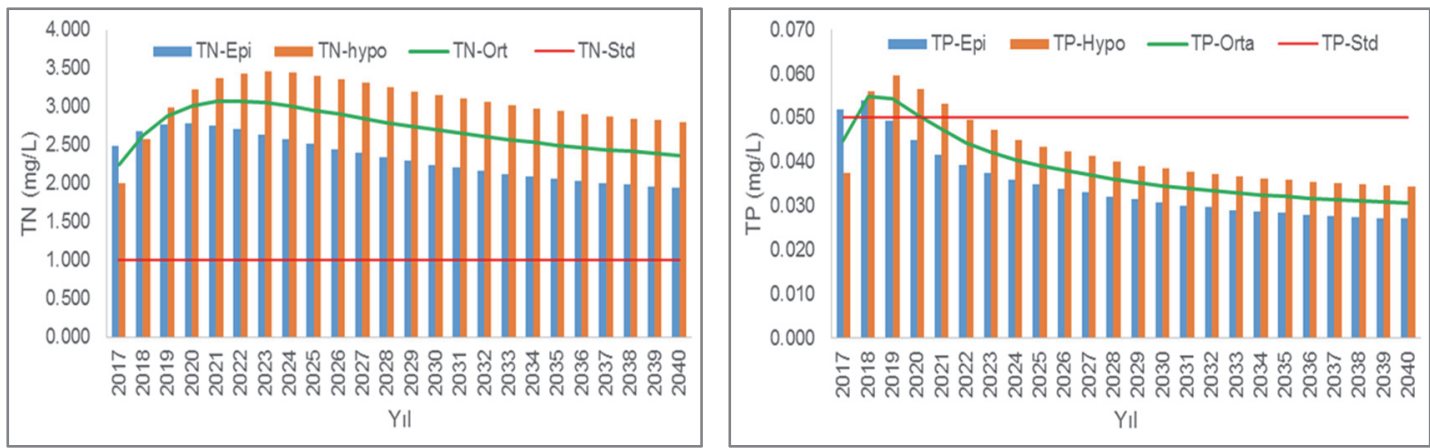

Figure 5. Temporal changes in TP and TN concentrations - scenario 1.

Scenario 2: Assuming continuity of current trends and no water abstraction for drinking purpose, it was observed that trophic level of the dam will be mesotrophic in terms of TN after 2027 and it remains mesotrophic in terms of TP (see Figure 6).
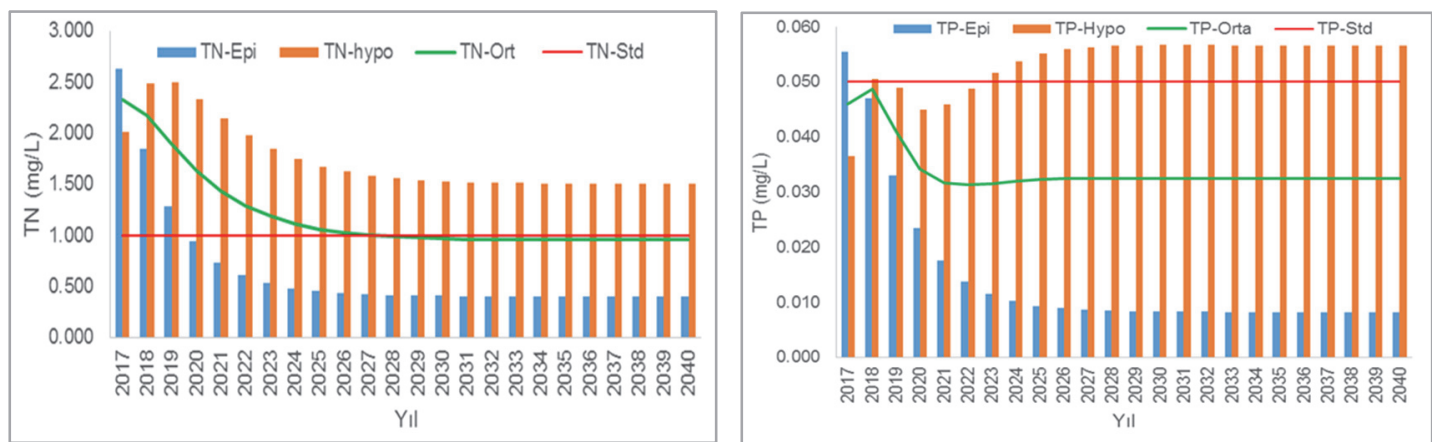

Figure 6. Temporal changes in TP and TN concentrations - scenario 2. 
Scenario 3: Evaluating the changes in water quality due to climate change it was observed that trophic level of the dam will be mesotrophic in terms of TN after 2020 and it remains mesotrophic in terms of TP. This situation could be interpreted such that the decline in precipitation rates causes decrease in $\mathrm{TN}$ loads transported with surface runoff (see Figure 7).
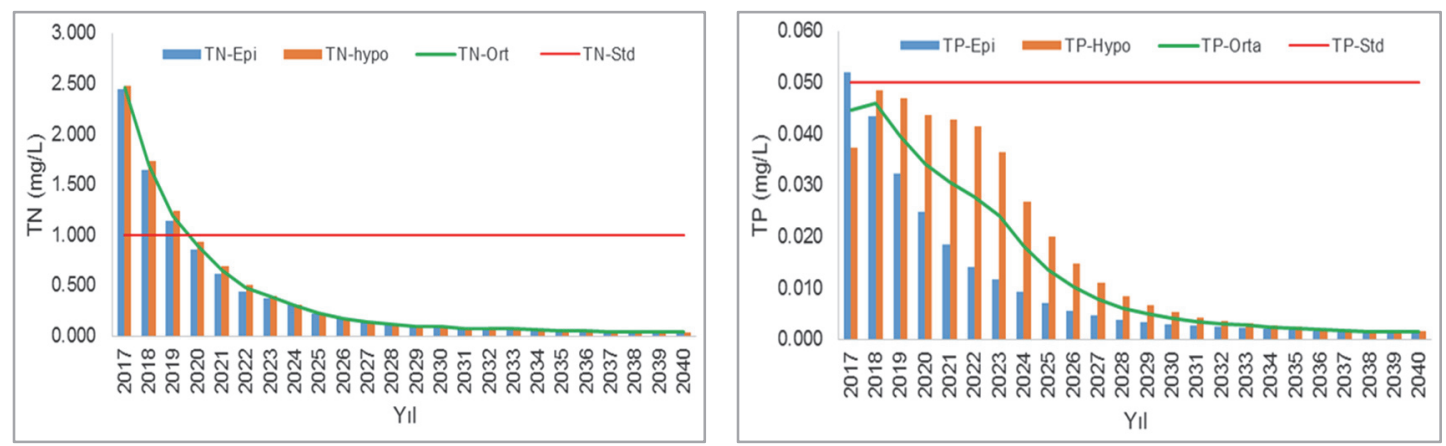

Figure 7. Temporal changes in TP and TN concentrations - scenario 3.

Scenario 4: Evaluating the effects of climate change and no water abstraction for drinking purpose, it was observed that trophic level of the dam will change from hypertrophic to eutrophic in terms of TN hence 2023 and it remains mesotrophic in terms of TP apart from the fact that it will be eutrophic in 2018 and 2037 (see Figure $8)$.
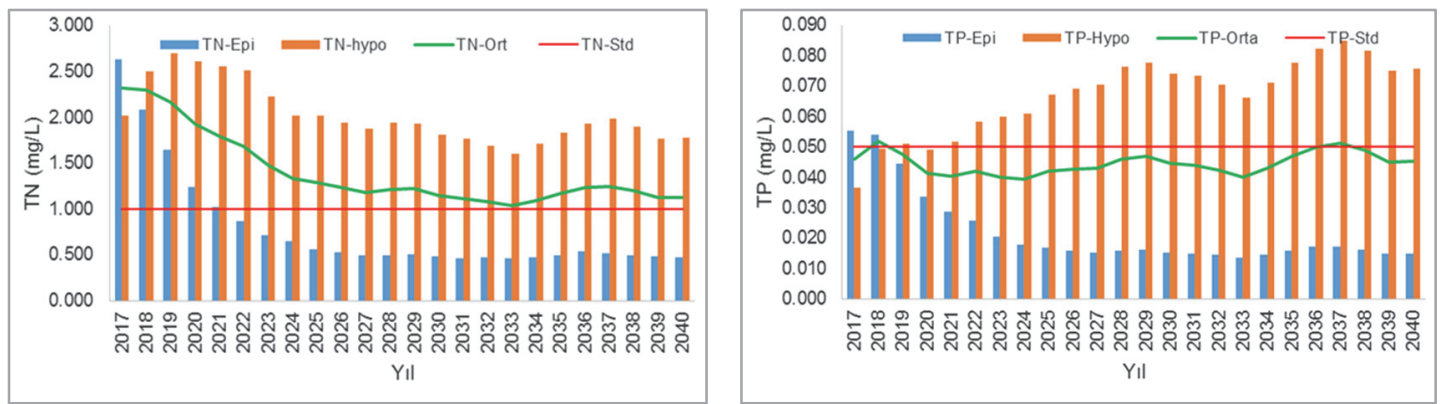

Figure 8. Temporal changes in TP and TN concentrations - scenario 4.

Even if the worst conditions occurred with Scenario 1 in terms of TN, it was thought that the probability of realization of this scenario is low. Therefore, scenario 4 was considered as the worst case and the measures were developed to reduce pollution loads predicted in this scenario. The model results indicated that trophic level 
of the Kartalkaya Dam will be mesotrophic in terms of TN and TP within 5 years in case of providing a minimum $50 \%$ reduction in $\mathrm{TN}$ and a minimum $25 \%$ reduction in TP for the estimated pollution loads in Scenario 4 (see Figure 9).

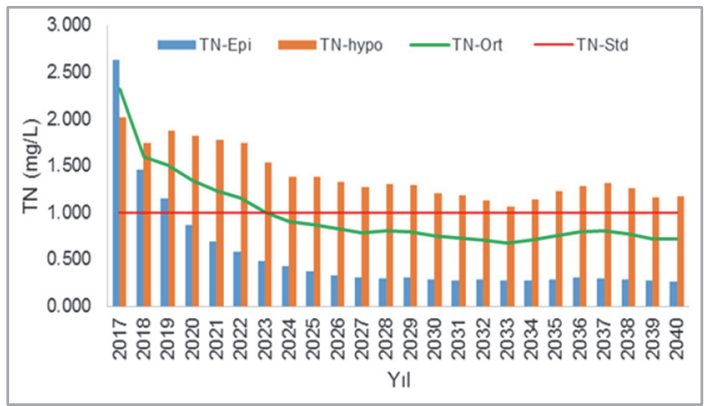

Figure 9. Temporal changes in TP and TN concentrations - implementation of pollution reduction measures.

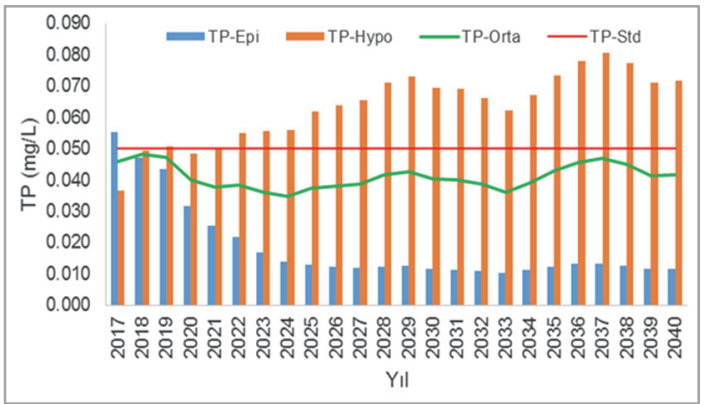

In order to increase feasibility of measures, it was recommended to decrease pollution loads gradually by 2040 as given below.

- Until 2020: 35\% for Total Nitrogen, 20\% for Total Phosphorus

- Until 2025: 10\% for Total Nitrogen, 5\% for Total Phosphorus

- Until 2040: 5\% for Total Nitrogen

Based on specified reduction rates and time schedule, a pollution reduction scheme was suggested (see Figure 10). In this scheme, it was proposed that measures will be executed in three phases, namely, the short term (2016-2020), medium term (2020-2025) and long term (2025-2040). When the measures were prioritized, both the basin's priorities and mandatory pollution control practices were considered.

Since proposed short-term measures would incur financial costs, an assessment was conducted to determine how much should be invested for the implementation and maintenance of these measures. According to the assessment, the likely cost of interventions will be around 59 million TL in total over time. The expected investments for wastewater collection, wastewater disposal and rehabilitation of landfill site will be 14, 43 and 2 million TL respectively. The details of initial investment costs and operating costs of each measure are shown in Table 3. 


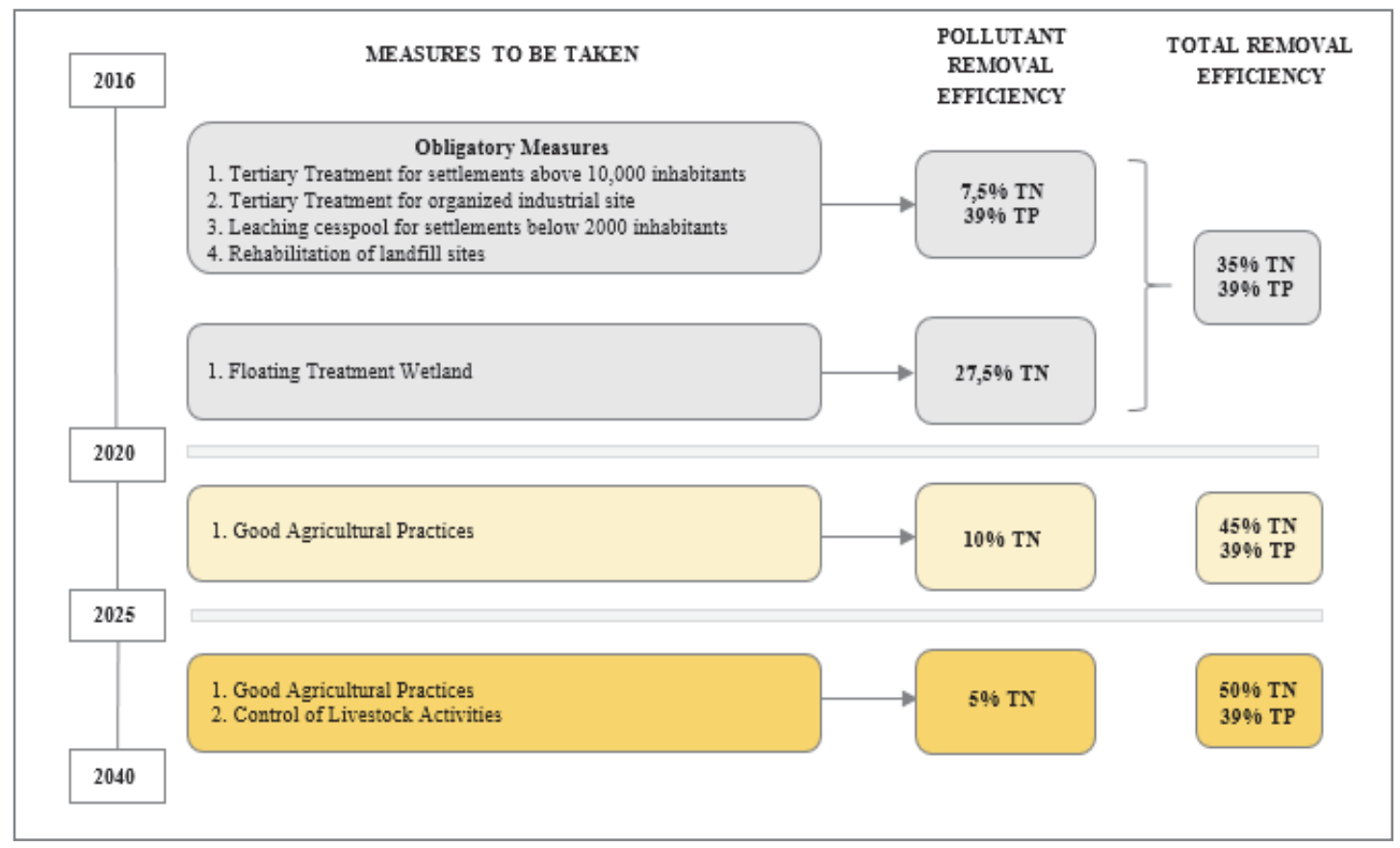

Figure 10. Pollution reduction scheme for the Kartalkaya Dam Basin.

Following the calculation of total costs, their distribution between stakeholders was analyzed. According to this analysis, the cost per capita will be 519 TL if inhabitants of the basin bear all the cost; on the other hand, this figure will drop to 23.3 TL if water users in Gaziantep also make payment for measures.

In order to assess the efficiency of proposed measures, the estimated costs were compared with the estimated economic benefits. If the net present value of benefits exceeds the net present value of the costs, the measures can be interpreted as sound and feasible. Therefore, it was expected that the net present value of the benefits will be more than 59 million TL. In this context, the annual per capita benefit of 47 TL ( $€$ 11.75 ) is enough to make the project economically profitable when considering only the benefits to the inhabitants of the basin; on the other hand, a benefit value of $2.2 \mathrm{TL}$ $(€ 0.55)$ per person per year is sufficient when the benefits to both the inhabitants of the basin and the water users were taking account. Although these values are far below the estimated benefits provided by the ECOTEC study, it was determined that this range of benefits is even enough to make the project feasible. 
Table 3

Investment and Operating Costs of Proposed Measures

\begin{tabular}{|c|c|c|}
\hline Measure & $\begin{array}{l}\text { Initial Investment Cost } \\
\text { (Thousand TL) }\end{array}$ & $\begin{array}{l}\text { Operating Cost } \\
\text { (Thousand TL) }\end{array}$ \\
\hline Renewal of main collector line of Pazarcik as discrete system & 12.458 & 779 \\
\hline Renewal of pumping stations in Pazarck & 226 & 133 \\
\hline $\begin{array}{l}\text { Removal of wastewater from municipal social facility area } \\
\text { located in absolute protection area }\end{array}$ & 106 & 52 \\
\hline $\begin{array}{l}\text { Conversion of Gölbaşı Wastewater Treatment Plant to } \\
\text { advanced biological plant }\end{array}$ & 6.864 & 16.471 \\
\hline $\begin{array}{l}\text { Conversion of Planned Çağlayancerit Wastewater Treatment } \\
\text { Plant to advanced biological plant }\end{array}$ & 4.872 & 7.527 \\
\hline $\begin{array}{l}\text { Construction of biological treatment facilities for settlements } \\
\text { with more than } 2,000 \text { inhabitants }\end{array}$ & 2.221 & 4.624 \\
\hline $\begin{array}{l}\text { Construction of leaching cesspool for settlements with less } \\
\text { than } 1,000 \text { inhabitants }\end{array}$ & 81 & 0 \\
\hline Transport of wastes from dump sites to sanitary landfill & 1.862 & 0 \\
\hline
\end{tabular}

\section{Discussion and Conclusion}

Kartalkaya Dam is of capital importance for water supply to Gaziantep metropolitan area, where almost 2 million people reside. However, Kartalkaya Dam has been under the pressure of human activities such as inadequate treatment of domestic and industrial wastewater, the unconscious use of fertilizers and pesticides, and disposal of wastes. Due to these pollutant activities, the water quality is at risk of deteriorating. To reverse this situation, a drinking water protection plan for the Kartalkaya Dam Basin was developed.

Within the management planning process, a series of scientific studies were conducted to identify and prioritize the management actions for the mitigation of water contamination risks to an acceptable level. As a part of planning process, a coupled water quality model for Kartalkaya Dam Basin was operated to estimate the effects of the pollutants on the water quality of the reservoir. The model was then used for 
scenario analysis. Based on this analysis, it was concluded that the pollutant loads from both point resources and non-point sources should be controlled in order to improve the water quality to levels in line with the regulatory standards. In this respect, a point/nonpoint source pollution reduction scheme was recommended. Additionally, a preliminary economic assessment was conducted and it was revealed that recommended measures for improvement of water quality to mandatory standards is feasible.

Consequently, the simulation results proved that the measures proposed for reduction of water pollution can lead to fulfilment of the limits required by the legislation, and sufficient financing can be obtained for pollution reduction scheme. However, planning attempts cannot succeed in practice without enduring political will, long-term support of public, allocation of adequate funds, and well-designed control, monitoring and enforcement processes.

\section{Acknowledgement}

This study was supported by General Directorate of Water Management, the Ministry of Forestry and Water Affairs. The author thanks to the executive of "Project on Water Quality Monitoring, Reference Point Determination and Modelling of Kartalkaya Dam Basin", İO Environmental Solutions Research and Development Co., and all the experts and academicians involved in this project for their valuable supports. 


\section{References}

Al Ibrahim, A. \& Patrick, R.J. (2017). Source water protection planning and management in Metropolitan Canada: A preliminary assessment. Water, 9(7), 497-510. Retrieved from http://www.mdpi.com/2073-4441/9/7/497

Buncle, A., Daigneault, A., Holland, P., Fink, H., Hook, S. \& Manley, M. (2013). Cost-benefit analysis for natural resource management in the pacific: A guide. Retrieved from http://www.adaptationundp.org

ECOTEC Research \& Consulting Limited. (2001). The benefits of compliance with the environmental acquis for the candidate countries. Retrieved from http://ec.europa.eu/environment/archives/ enlarg/pdf/benefit_c.pdf

General Directorate of Water Management. (2016). The project of impacts of climate change on water resources. The Ministry of Forestry \& Water Affairs, Ankara, Turkey. Retrieved from http://suyonetimi.ormansu.gov.tr/AnaSayfa/Projeler.aspx?sflang=tr

Loucks, D.P. \& van Beek, E. (2017). Water resource systems planning and management: An introduction to methods, models, and applications. Retrieved from http://unesdoc.unesco.org/images/0014/ 001434/143430e.pdf

Moriasi, D.N., Arnold, J.G., Van Liew, M.W., Bingner, R.L., Harmel, R.D. \& Veith, T.L. (2007). Model evaluation guidelines for systematic quantification of accuracy in watershed simulations. American Society of Agricultural and Biological Engineers, 50(3), 885-900. Retrieved from https://naldc.nal.usda. gov/naldc/download.xhtml?id=929\& content=PDF

Sklenar, K., Sham, C.H. \& Gullick, R.W. (2012). Source water protection vision and roadmap. Retrieved from http://www.waterrf.org/PublicReportLibrary/4176b.pdf

Ziemińska-Stolarska, A. \& Skrzypski, J. (2012). Review of mathematical models of water quality. Ecological Chemistry and Engineering S., 19(2), 197-211. Retrieved from https://www.degruyter.com/downloadpdf/j/eces.2012.19.issue-2/v10216-011-0015-x/v10216011-0015-x.pdf 


\section{Extended Turkish Abstract \\ (Genişletilmiş Türkçe Özet)}

\section{İçme Suyu Kaynaklarının Korunmasına Yönelik Planlama Süreci: Kartalkaya Baraj Havzası Örneği}

Gaziantep iline, 1986 yılından itibaren Kartalkaya Barajı'ndan içme ve kullanma suyu temin edilmekte olup ilin tek yüzeysel içme suyu kaynağı olması sebebiyle kaynağın korunması büyük bir önem taşımaktadır. Bununla birlikte, Kartalkaya Barajı, havzada yer alan evsel ve endüstriyel deşarjlardan kaynaklanan noktasal kirleticiler ile tarımsal alanlardan ve çöp depolama sahalarından kaynaklanan yayılı kirleticiler nedeniyle kirlenme tehdidi altındadır. Bu çerçevede, Kartalkaya Barajı'nın su kalitesi ve miktarının korunması ve sürdürülebilir kullanımının sağlanması maksadıyla koruma tedbirleri belirlenmiş ve bu tedbirleri içeren bir içme suyu havzası koruma planı hazırlanmıştır. $\mathrm{Bu}$ çalışmanın amacı, Kartalkaya Baraj Havzası'nın korunmasına yönelik yapılan planlama çalışmasının teorik çerçevesini değerlendirmek ve kapsamlı bir içme suyu koruma planı oluşturulması için gerekli araçları ortaya koymaktadır.

İçme suyu koruma planlarıyla su kalitesinin iyileştirilmesi ve sürdürülebilirliğinin sağlanması için havza özelinde en uygun arazi kullanımının ve koruma tedbirlerinin belirlenmesi amaçlanmaktadır. Koruma planlarının hazırlanması, havza karakterizasyonunun ortaya konması, kirletici kaynakların tespiti, su kalitesinin analizi, alternatif gelecek senaryoları için su kalitesinde meydana gelebilecek değişimlerin tespiti, kirliliğin azalmasını sağlayacak tedbirlerin belirlenmesi, önerilen tedbirlerin faydamaliyet analizi aşamalarından oluşmaktadır.

Bu kapsamda, öncelikle Kartalkaya Baraj Havzası'nın teknik ve sosyo-ekonomik özellikleri havzada yürütülen çalışmalar ve mevcut verilere dayalı olarak tespit edilmiş; böylece havzanın mevcut durumu ortaya konmuştur. Ayrıca yerüstü sularının ve rezervuarın kalitesinin belirlenmesi amacıyla bir su yılını kapsayacak şekilde izleme çalışmaları yürütülmüştür. İzleme çalışmaları kapsamında, yüzeysel su kaynakları boyunca 10 istasyonda; rezervuarda ise 8 istasyonda numune alımı gerçekleştirilmiştir. İstasyonların yerleri kirletici kaynaklar göz önünde bulundurularak seçilmiştir. Yerüstü sularından alınan numunelerin analizleri, Yerüstü Su Kalitesi Yönetmeliği’nde yer alan her bir parametreye göre gerçekleştirilmiş ve analiz sonuçları yönetmelikte belirtilen kalite kategorilerine göre değerlendirilmiştir. Diğer taraftan, rezervuardan alınan numuneler, İçme Suyu Elde Edilen veya Elde Edilmesi Planlanan Yüzeysel Suların Kalitesine Dair Yönetmeliği’ndeki 41 parametre için analiz edilmiş ve analiz sonuçlarının değerlendirmesi yönetmelikteki kalite kategorilerine göre yapılmıştır. İzleme sonuçları, su kalitesinin membadan mansaba doğru düştüğünü, yerüstü sularında nütrient konsantrasyonlarının yüksek olduğunu ve bakteriyolojik açısından kirlenme oluştuğunu göstermektedir. Yerüstü sularındaki analiz sonuçlarına paralel olarak, rezervuardaki nütrient ve bakteriyolojik parametrelerin Yönetmelikteki limit değerleri aştı̆̆ tespit edilmiştir.

İlaveten, Kartalkaya Baraj Gölü havzasında mevcut arazi kullanımının su kalite ve miktarına olan etkisini değerlendirmek maksadıyla matematiksel modelleme çalışmaları yapılmıştır. Bu amaçla çalışmada MapShed ve STELLA dilinde yazılmış su kalite modeli birlikte kullanılmıştır. MapShed yazılımıyla havzada çeşitli arazi kullanım uygulamaları sonucunda baraja taşınabilecek kirletici yüklerin belirlenebilmesi, STELLA dilinde yazılmış su kalite modeliyle de bu yüklerin baraj su kalitesi üzerine etkilerinin ortaya konulması hedeflenmiştir. Kalibre edilen MapShed Modeli ile 2017-2040 
yılları arasında baraja gelebilecek su miktarı ve kirletici yükler tahmin edilmiş, su kalite modeli ile de bu kirletici yükler altında baraj su kalitesinin 2017-2040 yılları arasında nasıl değiştiği incelenmiştir.

Modelleme çalışması kapsamında, Kartalkaya Barajı'nda MapShed Modeli 2000-2012 yılları arasında günlük çalıştırılarak akım değerleri tahmin edilmiştir. DSİ tarafından işletilen 12020002 no'lu akım gözlem istasyonu verileri kullanılarak akım değerleri kalibre edilmiş̧ir. Model performans parametresi olarak Nash-Sutcliffe katsayısı kullanılmıştır. Ayrıca, MapShed ile akarsulardaki besi maddesi konsantrasyonları da 2000-2012 yılları arasında tahmin edilmiştir. Besi maddesi konsantrasyonlarının kalibrasyonu için Aksu Nehri'nin mansabında yapılan su kalite izleme çalışmasının sonuçları kullanılmıştır. Model performans katsayısı olarak MAE (ortalama mutlak hata), RMSE (kök ortalama kare hatası) ve rRMSE (nispi kök ortalama kare hatası) kullanılmıştır. Model performans katsayıları, hem debi değerleri hem de besi elementleri için modelin performansının kabul edilebilir düzeyde olduğunu göstermiştir. Kalibre edilen MapShed modeli kullanılarak 2017-2040 yılları arasında akarsu debisi ile kirletici yükleri her yıl için ayrı ayrı hesaplanmıştır. Orman Su İşleri Bakanlığı tarafından 2016 yılında tamamlanan İklim Değişikliğinin Su Kaynaklarına Etkisi Projesi’nin çıktılarından faydalanılmış olup havza alanı için en uygun sonuçların üretildiği MPI-ESM-MR modeli RCP4.5 senaryosunda 2017-2040 yılları için elde edilen sıcaklık ve yağış parametreleri kullanılmıştır. Böylelikle elde edilen debi değerlerinde iklim değişikliğinin olası etkileri dikkate alınmıştır. Sonuç olarak, Mapshed modeli TN yükünün ortalama \%10'unun TP yükünün ise ortalama \%61'inin noktasal kaynaklardan su kütlesine geldiğini ortaya koymuştur. Mapshed modeline ilaveten, Kartalkaya Barajı'nın aylık ortalama su kalitesi parametrelerini tahmin edebilmek üzere bir su kalite modeli tasarlanmıştır. Modelin oluşturulmasında STELLA yazılım programı kullanılmıştır. Modelin kalibrasyonu için 2016 yılında yürütülen izleme programı kapsamında alınan su numunelerine ait analiz sonuçları kullanılmıştır. Ölçülen su kalitesi değerleri ile modelin hesapladığı değerler arasındaki fark, modelde kullanılan katsayılar değiştirilerek MAE, RMSE ve rRMSE ölçütlerine göre minimize edilmiştir. Kalibre edilen su kalite modeli ile havza için geliştirilen 4 farklı senaryo neticesinde baraj gölü trofik seviyesinde meydana gelebilecek değişimler analiz edilmiştir. Bu amaçla, Yerüstü Su Kalitesi Yönetmeliği'nde verilen sınır değerler dikkate alınmıştır. Su kalite sınıfı açısından en kötü koşullar Senaryo 4 (havzada iklim değişikliğine bağlı etkilerin görülmesi ve barajdan içme suyu maksatlı su çekiminin yapılmaması) ile ortaya çıkmış ve kontrol önlemleri bu senaryo üzerinden geliştirilmiştir. Bu çerçevede, Senaryo 4'deki kirlilik yüklerinde TN için minimum \%50'lik bir azalma TP yüklerinde ise minimum \%25'lik bir azalma sağlanması durumunda su kalite sınıfının 5 yıl içinde TN ve TP için mezotrofik kalite sınıfında olacağ 1 tespit edilmiştir. Belirlenen hedeflerin 2040 yılına kadar kademli olarak düşürülmesi önlemlerin uygulanabilirliğini arttıracağından 2020 yılına kadar TN için \%35, TP için \%20; 2025 yılına kadar TN için \%10, TP için \%5 ve 2040 y1lına kadar TN için \%5 azalma öngörülmüş̧ür. Söz konusu azaltım oranlarının sağlanması için koruma planı kapsamında öncelikle yasal zorunluluk gereği alınması gereken önlemlerin (atıksuların ve atıkların kontrolü) yerine getirilmesi; ilaveten, baraj gölüne yüzer sulak alan yapılması önerilmiştir. Orta ve uzun vadede ise tarımsal ve hayvansal faaliyetlerden kaynaklı kirlilik yüklerinin azaltılmasını sağlayacak uygulama yöntemlerinin hayata geçirilmesi hedeflenmiştir.

Ayrıca, kısa vadede yatırım gerektiren hükümlerin maliyetleri ortaya konulmuş ve bu maliyetler için ekonomik değerlendirme yapılmış ve planlanan tedbirlerin net bugünkü değeri 58.274.336 TL olarak belirlenmiştir. Sadece havza nüfusu göz önünde bulundurulduğunda alınacak tedbirlerin kişi başına maliyetinin 519 TL olduğu; Gaziantep nüfusu da hesaba katıldığında bu rakamın 23,3 TL'ye düştüğü görülmüş̧ür. Alınması planlanan tedbirlerin ekonomik faydalarına bakıldığında, yıllık kişi başına faydanın asgari $47 \mathrm{TL}$ olması durumunda tesisin ekonomik net bugünkü değerinin pozitif olacağı; Gaziantep nüfusu dikkate alındığında ise kişi başına faydanın asgari 2,2 TL olmasının projeyi 
ekonomik yönden karlı kılacağı tespit edilmiştir. Su temini, atıksu toplama ve atıksu arıtma alanlarına yatırım yapan projelerin yıllık kişi başına faydasının 28 ila 68 Euro aralığında olduğu bilgisinden hareketle, koruma planında yer alan tedbirlerin ekonomik yönden yapılabilir olduğu sonucuna varılmıştır. 